\title{
O INCENTIVO FISCAL COMO INSTITUTO DE DIREITO ECONÔMICO
}

\author{
SERGIO D'ANDREA FERREIRA*
}

I - $O$ direito econômico, sua autonomia e vinculaçōes

1. O Direito Econômico, ramo do Direito Social, é o Direito da Ordem Econômica, com suas raízes e contornos na Constituifão Federal (Título VII).

Tem por objeto as situaçōes, as relaçōes jurídicas, os poderes, deveres, direitos, obrigaçōes, pretensões, ações de que participam o Estado, como agente normativo e regulador da atividade econômica (CF, art. 174) e como explorador desta (art. 173), e dos demais sujeitos econômicos, do setor público e do setor privado.

2. A Carta Política Nacional conferiu identidade ao Direito Econômico, em face do Direito Financeiro, do Direito Tributário, do Direito Administrativo, e dos demais ramos jurídicos, eis que referido nominalmente no art. 24 , I, da CF.

Assinale-se que o dispositivo coloca o Direito Econômico como matéria da competência concorrente da União, dos Estados e do Distrito Federal.

3. A ordem econômica nacional consagra o sistema de economia capitalista, de mercado, fundada na propriedade dos meios de produção, na livre iniciativa, na. organização da empresa e na atividade do empresário, a, legitimamente, buscar o lucro, e usar o poder econômico, sendo reprimidos, tão-somente os abusos respectivos: CF, arts. 170, caput, e incisos II e IV; e 173, $\$ 4^{\circ}$.

Sem tisnar o seu caráter de economia descentralizada, aparece o Estado, como empresário, como sujeito econômico (art. 173), ou como agente normativo e regulador, mas, tão-só, na qualidade de fiscalizador, incentivador e planejador, sendo que, nesta última função, com papel simplesmente indicativo no concernente ao setor econômico privado (art. 174).

4. O Brasil ingressa, contemporaneamente, em termos mais incisivos, no real regime da economia de mercado, tendo, conforme gizado, a livre iniciativa como

- Professor Titular no Rio de Janeiro. Advogado. Consultor Jurídico. Desembargador Federal aposentado. Ex-membro do Ministério Público Estadual. Da Academia Brasileira de Letras Jurfdicas e do Instituto dos Advogados Brasileiros.

R. Dir. Adm.,

Rio de Janeiro, 211: 31-46, jan./mar. 1998 
fundamento da ordem econômica, e como princípios dessa a propriedade privada e a livre concorrência, consagrando a legitimidade do poder econômico não-abusivo e do lucro não arbitrariamente aumentado.

A livre iniciativa, reconhecida como valor social, é, aliás, um dos fundamentos da República Brasileira, enquanto Estado Democrático de Direito (art. 1², IV); e a participação é expressão de outros desses fundamentos, a cidadania (art. $1^{2}$, II).

5. Nesta ambiência jurídico-social, é que tem de ser normatizado, interpretado, vivenciado, executado e aplicado o Direito Econômico Brasileiro, o que aliás, se insere nas tendências e vertentes do Direito Comparado Contemporâneo, e isso inclusive no tópico que ora nos interessa, de suas vinculações com o Direito Tributário.

6. Em verdade, os demais ramos jurídicos, do ius privatum, do ius sociale e do ius publicum, que com o Direito Econômico se inter-relacionam, preservada a autonomia de cada um, o instrumentalizam, em várias hipóteses, em contexto jurídico com forte conjunto interseção.

É o que será desenvolvido, no presente estudo em sede de incentivos fiscais.

II - A consensualidade e a segurança como marcas dos direitos público e social atuais

1. Sinetes da atividade governamental, no Direito Público e Direito Social do Estado forte, tentacular, como o Estado Intervencionista, são a unilateralidade, a imperatividade, as situações regulamentares ou estatutárias, a discricionariedade, a revogabilidade dos atos, a auto-executoriedade.

2. Neste contexto conceitual, é que se forjaram o Direito Público e o Direito Social Brasileiros tradicionais, revestidos dessas características e com suas bases fincadas na estrutura e no funcionamento governamentais decorrentes da Revoluçäo de 30; características que se adensaram no Estado Novo e atingiram a quadra autocrática do Período Revolucionário de 1964, sem que os breves períodos de arejamento democrático as tivessem, até então, alterado substancialmente.

3. Os Direitos Público e Social Comparados oferecem, como marca de sua modernidade a negociação, o que se apresenta como uma forma de privatização, de desestatizaçāo, de democracia participativa, de parceria (cf. Foundations of Administrative Law, PETER H. SCHUCK, Oxford University Press, 1994, p. 290 e 312 e s.).

4. É inevitável, portanto, que o Brasil siga a mesma trilha do Direito Comparado, no sentido da substituição da unilateralidade pela bi ou multilateralidade, com a formação das situações jurídicas de Direito Público e Social, inclusive o Econômico, mercê da presença necessária, para o aperfeiçoamento do vínculo, de duas ou mais partes a expressarem sua vontade jurígena - plurilateralidade existencial -; e a provocarem o nascimento de direitos e obrigaçōes recíprocos, de prestações e contraprestações - multilateralidade eficacial.

Gize-se, desde logo, ponto relevante para o presente estudo: como o ato bilateral nada mais é, como preleciona PONTES DE MIRANDA, do que a fusão de atos 
unilaterais, e como, outrossim, o ato unilateral pode surgir em razão de acordos, ajustes, compromissos antecedentes, sendo, apenas, uma expressão jurígena necessária à consumação da situação jurídica plural, não interfere com esse esquema o fato de haver um ato unilateral culminante, que aperfeiçoa, em definitivo, a referida situação, e lhe enseja a irradiação irreversível de seus efeitos jurídicos.

Este quadro é, em geral, tornado transparente, através dos consideranda que integram aquele que constitui o mencionado ato unilateral final.

5. Neste panorama insere-se o fenômeno de retomada, com vestes atualizadas, da relevância da noção dos atos governamentais de gestão, do ius gestionis, a envolver práticas com irradiação de efeitos jurídicos no setor privado da economia, que a Carta Magna Nacional identifica e protege, diferençando-o do setor público, quando, em seu art. 174, ao tratar da função governamental de planejamento, estabelecer que este será determinante para o último, e simplesmente indicativo para o primeiro.

É certo que, cognato, está o exercício do ius imperii, eis que se trata de ato de direito público. Mas a imperatividade exsurge com sentido próprio, apresentando sua força impositiva para as partes e para terceiros; sua eficácia autovinculativa para seu autor, e vinculadora para o outro ou outros lados do negócio jurídico, tudo a traduzir o caráter obrigacional da situação jurídica criada.

6. Este tópico encontra-se ligado à hegemonia, de que modernamente desfruta, na principiologia jurídica, o princípio da segurança jurídica.

\section{III - A relação jurídica de incentivo econômico}

1. A Constituição Federal de 1988 destacou, como uma das formas de atuação do Estado, na qualidade de agente econômico, a função de incentivo: art. 174.

2. Não se pode, no atual regime constitucional brasileiro, falar-se de intervenção estatal na economia, da mesma forma que se fazia em regimes anteriores, pois que, se socializada em muitos pontos, a Carta Política Nacional, pelos princípios e regras que contém, balizou, de modo estrito, conforme antes assinalado, a presença governamental em relação à atividade econômica.

Assim, ao contrário das Constituiçōes antecedentes (CF, de 1946, art. 146; CF de 67/69, art. 163), a vigente não previu a intervenção no domínio econômico (salvo sob a forma prevista no art. 149), definindo, como já indicado, a participação do Estado, na economia, sob três formas: (a) explorador direto da atividade econômica: art. 173, e §§; (b) agente normativo da mesma: art. 174; (c) seu agente regulador: art. 174.

Nas formas $b$ e $c$, três funções podem ser exercitadas: a de fiscalização, a de incentivo e a de planejamento.

3. Verifica-se que, no desempenho dessas três funções, o papel estatal pode ser normativo ou executivo, e, assim, criador de situações jurídicas objetivas, abstratas e em tese; ou de situaf̧ões subjetivas e in casu.

Acentue-se que, sendo funções, são atividades vinculadas, comprometidas finalisticamente. 
4. Desta última área é próprio o incentivo, que CELSO RIBEIRO BASTOS (Comentários à Constituição do Brasil, São Paulo, Saraiva, 1988, $7^{\circ}$ vol. p. 108), citando a lição de GERALDO DE CAMARGO VIDIGAL (A Constituição Brasileira, FU, 1988, p. 381), afirma ser

"a mais moderada forma de presença do Estado na economia".

Por que moderada?

Exatamente porque não é impositiva, unilateral, mas exige o acordo de vontades, do incentivante e do incentivado, acordo gerador de situação jurídica subjetivada.

5. Na linha do que preleciona DIOGO DE FIGUEIREDO MOREIRA NETO (Curso de Direito Administrativo, Rio, Forense, 10a ed., p. 401 e s.), destaquemos o fomento público no concerto da atividade administrativa, por sua identidade na principiologia e no ideário da Constituição Federal, que erige o desenvolvimento nacional como um dos valores sociais a serem assegurados pelo Estado Democrático de Direito Brasileiro: preâmbulo e art. 3ํ. II.

5.1. O estímulo da AP às iniciativas individuais caracteriza-se, na linha da modernidade do Direito Administrativo, pela ausência da compulsoriedade, da impositividade, na fruição dos meios de fomento; e pelo uso da premiação, em vez da coação.

5.2. É certo que, se a formação da relação jurídico-administrativa de fomento público não é ex lege ou cogente, uma vez constituída, o particular tem pretensão jurídica à manutenção e à efetivação do incentivo, não-passível de revogação discricionária.

Constitui-se relação jurídica fechada entre as partes, com vínculo de crédito e débito, dotado o incentivado de poder de efetivação (ação) dos direitos subjetivos adquiridos e de poder de exigência (pretensão) das correlatas obrigações criadas.

5.3. A variedade de instrumentação estimulativa não afasta a subjetivação das situaçōes juridicas decorrentes, no campo do fomento econômico, sendo o incentivo instituto de Direito Constitucional, conforme salientado.

Podem ser utilizados meios de Direito Privado (a concessão de crédito, de financiamento), de Direito Financeiro (o subsídio), a gerarem, na referida subjetivação situacional, a vinculação governamental.

6. Uma das armas mais relevantes, eficientes e comuns do arsenal fomentador é o incentivo fiscal.

Como salienta DIOGO FIGUEIREDO MOREIRA NETO (op. cit., p. 419), "é o campo da função metafiscal do tributo", seu "efeito metatributário positivo", estimulante.

6.1. Podendo assumir as modalidades mais diversificadas, em que se destaca a isenção fiscal, sua marca é a autovinculação, na caracterização das situações subjetivas.

E o ponto de convergência entre o Direito Tributário e o Direito Econômico, ou seja, o emprego dos institutos do primeiro instrumentaliza os do segundo, na fixação, precisamente, da vinculação jurídica.

6.2. A isenção é instituto fiscal que tem por efeito a exclusão do crédito tributário, impedindo a prática do ato administrativo do lançamento (CTN, arts. 139, 142 e 175, I), pela esterilização do fato gerador (arts. 113 e 114). 
Mas ela vem associada com a utilizaçāo de institutos de outros ramos jurídicos, perfeitamente encaixados na Teoria Geral do Direito.

Assim, $o$ art. 176 do CTN refere, expressamente, a instrumentalização da isenção através de contrato.

6.3. Outrossim, o art. 178 contempla, expressamente, a vinculação governamental, fonte de direitos subjetivos adquiridos do destinatário, à isenção concedida por prazo certo e em função de determinadas circunstâncias, o que veio a ser objeto de enunciação pelo SUPREMO TRIBUNAL FEDERAL, no verbete $n^{2} 544$ de sua Súmula:

"Isençōes tributárias concedidas, sob condição onerosa, não podem ser livremente suprimidas."

Há de considerar-se que a onerosidade, atributo da relação jurídica que acarreta vantagens e ônus para as várias partes envolvidas, terá de ser entendida como determinante de proveito, não necessária ou exclusivamente em favor do Poder Público, mas sim em prol do interesse da coletividade, que o Estado encarna, da forma como o diz DIOGO DE FIGUEIREDO (op. cit., p. 401): “não para a exaltação do Estado, mas para o bem de todos" (arts. 12, $2^{2}$ e $3^{2}$ da CF).

Sublinha HUGO DE BRITO MACHADO (Curso de Direito Tributário, São Paulo, Malheiros, $12^{2}$ ed. 1997, p. 155/156):

“ $O$ Estado, assim como pode tributar, pode também, evidentemente, revogar as isençōes concedidas. Entende-se, porém, que o contribuinte pode ser atraído pelo incentivo que a isenção representa $e$, assim, passe a desenvolver atividade em que não se lançaria, se nāo existisse a isenção, fazendo investimentos vultosos e ficando mesmo em situação de não poder, sem graves prejuizos, desistir. Nestes casos, a retirada da isenção representaria um ludíbrio, sendo, portanto, inadmissivel. Assim, também, qualquer alteração que implique, direta ou indiretamente, redução da isenção é inadmissivel.

O Supremo Tribunal Federal, antes do advento do Código Tributário, já firmara jurisprudência no sentido da irrevogabilidade de isenções concedidas sob condição onerosa."

6.4. É que se tem de distinguir entre as isenções exclusivamente normativas, e aquelas que envolvem a prática de atos individualizadores e subjetivadores da situação de isenção, e que se inserem na categorização do incentivo econômico stricto sensu, contemplado no art. $174 \mathrm{da}$ CF.

7. Aspecto importante é que diversos são, de um lado, o ato administrativo de mera declaração do preenchimento dos requisitos legais de fruição da isenção, nos termos do art. 179 do CTN, e que não é gerador de direito adquirido ( $\$ 2^{2}$ do art. $179 \mathrm{e}$ art. 155), denominado, na linguagem correntia, de "ato administrativo que defere a isenção"; e, de outro, o ato constitutivo do direito à isenção, lastreado em espeque jurídico hábii.

7.1. Sempre lavrou, outrossim, na doutrina, com reflexos na jurisprudência e na própria estruturação do Código Tributário Nacional, polêmica a respeito da conceituação e, portanto, da própria natureza jurídica e efeitos da isenção.

Como detectam alguns autores, há hipóteses que são de verdadeira não-incidência, no sentido de que excepcionam, frontalmente, os casos de incidência. 
Para muitos, nestas hipóteses, haveria a ocorrência do suporte fático, mas esterilizado, impotente para gerar o direito-poder de efetuar o lançamento, e, portanto, de criar o crédito tributário. É o fato gerador isento, na nomenclatura de SAINZ DE BUJANDA, essencialmente distinto do fato gerador do tributo: a isenção impede o nascimento da obrigação tributária (Natureza jurídica das isenções tributárias, PEDRO LUCIANO MARREY JÚNIOR, in RDP, 25: 177). O que incide é a regra jurídica de isenção, cujo efeito é negar existência à relação jurídica tributária (ALFREDO AUGUSTO BECKER, Teoria Geral do Direito Tributário, 1963, p. 276).

Em certos casos, o fato gerador ocorre, mas, por considerações outras, inclusive extrafiscais, o débito tributário é inexigível (cf. AMÍLCAR DE ARAÚJO FALCÃO, Fato Gerador da Obrigação Tributária, 1964, p. 132); é dispensado o pagamento de um tributo devido (RUBENS GOMES DE SOUZA, Compêndio de Legislação Tributária, p. 70).

7.2. A isenção fiscal produto da prática de ato administrativo constitutivo, neutralizador da eficácia do direito potestativo de efetuar o lançamento, está bem compreendido, como salientado, na moldura do instituto do incentivo econômico, atualmente de matriz constitucional.

A matéria, portanto, desborda dos estritos limites do Direito Tributário, pois que, com a referida base na Carta Política Nacional, tem seu núcleo no Direito Econômico, sendo o Fiscal apenas um instrumento de realização daqueles, conforme é correntio.

A isenção extrafiscal, como acentua MARREY JÚNIOR (trabalho cit., p. 179), deixa de "exercer a função de instrumento da justiça tributária", e "converte-se em instrumento de uma política social e econômica": é a isenção "como estímulo ao desenvolvimento".

THEOTONNIO MONTEIRO DE BARROS (A Taxa e seus Principais Problemas, p. 73) giza:

"Quando lança e arrecada tributos, o Estado nem sempre tem em vista os mesmos fins. Ora busca pura e simplesmente a obtenção de meios pecuniários destinados a cobrir suas despesas; ora esse objeto assume um caráter secundário, figurando em plano principal uma finalidade social ou política."

7.3. Destaca-se a irrevogabilidade das chamadas isençōes condicionadas, contempladas no art. 178 do CTN: isenção a prazo certo e em função de determinadas condições.

7.4. Em verdade, não se trata de condictiones facti, modalidade de atos jurídicos, mas condições-cláusulas, conteúdo do ato jurídico concreto, a envolverem prestação e contraprestação, a bilateralidade eficacial, a onerosidade.

7.5. MARREY JÚNIOR (op. cit., p. 179 e s.) explana:

"SOUTO MAIOR BORGES, após afirmar que as isenções concedidas graciosamente, de modo incondicional, podem ser revogadas, adverte: 'Ao contrário, nas isençöes condicionais, a lei estabelece as condiçōes $e$ os requisitos para a sua concessão. Tais condições e requisitos, ordinariamente, exigem do titular da isenção, como pondera CARLOS MAXIMILIANO, esforço dispendioso, obra cara, imobilização de capitais próprios ou tomados a juros. 
Se, nessas circunstâncias, fosse juridicamente possível a cessação de plano da fruição do benefício fiscal, restabelecido total ou parcialmente o ônus da tributação, ninguém arriscaria seu futuro financeiro; ninguém acudiria aos acenos do Estado, através da legislação de incentivos fiscais, particularmente em matéria de isenções. A qualquer tempo, poder-se-ia dar a ruptura do equilíbrio financeiro do investimento privado, com a superveniência da lei revogadora.

Inatingiveis, portanto, as isenções de caráter bilateral (temporárias, condicionais ou contratuais). A regra da revogabilidade esbarra diante do direito adquirido ao gozo da isenção, enquanto persistirem as condições $e$ os requisitos em função dos quais esta foi outorgada' (Isençōes Tributárias, 1969, p. 96/97).

Concedida a isençāo por tempo determinado, nem o legislador nem a autoridade administrativa poderão, a qualquer tempo, revogá-la, vale dizer, retirá-la discricionariamente, antes de seu termo final de duração, legalmente prefixado. Nasce, com a concessão, direito subjetivo ao gozo da isenção tributária.

'Quando a isenção exprime uma abstenção legítima do poder de tributar, com ela nasce para o beneficiário direito subjetivo a usufruí-la, no tempo e com o conteúdo da lei instituidora, desde que a situação se ajuste às exigências feitas pelo legislador para outorgá-la. Satisfeitas essas exigências, o legislador não é livre de, sem mais nem menos, declará-la revogada' (SEABRA FAGUNDES, Revogabilidade das isençōes tributárias, RDA, 58:02).

Como vemos, a doutrina reconhece que, neste caso, as vantagens da isenção se incorporam ao patrimônio de seu beneficiário, que tem direito adquirido de gozar da vantagem econômica estipulada."

HELLY LOPES MEIRELLES (Isenção tributária condicionada, in Estudos e Pareceres de Direito Público, São Paulo, RT, 1971, p. 379 e s.) alude a "isenção negocial e bilateral", afastando a idéia de "liberalidade da Administração", ou "privilégio"; de "favor fiscal incondicionado e unilateral", pois que, concretizando a "contraprestação do poder tributante", produto de um "ato negocial".

É irrevogável, "porque ela se erigiu em direito adquirido".

A jurisprudência é neste sentido, proclamando o SUPREMO TRIBUNAL FEDERAL o caráter bilateral da isenção e a configuração do "ato juridico perfeito gerador de direito adquirido" (RE $\mathrm{n}^{\mathrm{0}}$ 70.559-ES, Relator Min. BILAC PINTO, julg. Em 12.12.78, DJ de 22.03.74).

7.6. E certo que MARREY JÚNIOR citado dissocia-se da maioria em tópico relevante:

"Nossa posição, ante a tão complexo e discutido problema, na prática, se identifica com a da maioria, se bem que partimos de outros pontos - para nós muito mais importantes - para chegarmos ao mesmo resultado.

Realmente, dentro da sua competência constitucional, o legislador é livre para fazer o que quiser. $O \S 3^{2}$ do art. 153, da Emenda Constitucional $n^{2} 01$, não inibe o legislador no sentido de impedi-lo de revogar uma isenção, concedida a que título for. Se aceitássemos tal orientação, estaríamos admitindo que o legislador, numa determinada legislatura, pode emanar uma norma, que irá vincular o legislador que o suceder, o que seria absurdo. Estaríamos, implicitamente, admitindo que o legis- 
lador precedente ocupava uma posição de superioridade em relação ao legislador que o sucedeu.

Se o legislador, atendendo a circunstâncias de ordem política, social, econômica etc. concede uma isenção, não fica absolutamente inibido de, no dia seguinte, revogar o benefício concedido.

O que a Constituição protege, através do $\S 3^{\circ}$ do art. 153 , é que o patrimônio do individuo beneficiado pela isenção revogada não seja prejudicado.

Se determinada pessoa preencheu os requisitos da lei para gozar do benefício de não pagar tributos por determinado prazo, seu direito diz respeito a que seu patrimônio tenha o gozo das conseqüências da vigência daquela lei, e não o direito de inibir a tarefa legislativa no sentido de se revogar a isenção. Caso a lei isentadora venha a ser revogada, o problema se resolverá em perdas e danos. $O$ direito que $o$ indivíduo tem em gozar o benefício da isenção jamais impedirá a revogação da lei que o concedeu.

No caso da revogação das isenções condicionais, o que ocorre é a responsabilidade do Estado pela circunstância de haver conferido um direito a alguém e, posteriormente, ter revogado esse direito.

Portanto, a proibição contida no art. 178 do CTN diz respeito - queremos crer - não ao impedimento da tarefa legislativa revogadora, mas, sim, à conseqüiente necessidade de o Estado reparar o dano ocasionado pela revogação da lei de isenção."

Cremos que a questão não é de obstaculização ao exercício do poder legiferante, mas de concretização da situação subjetivada por ato jurídico.

O que não pode ser revogado é o ato individualizador e subjetivador, fonte dos direitos adquiridos, da bilateralidade eficacial, da onerosidade, da intangibilidade.

O permissivo isentivo incidiu com a prática do ato especial e exauriu, no caso, sua função. Poderá ser revogada a lei, novas isençōes não mais poderão ser concedidas, mas as já conferidas, por ato de concretização, estão, por força da garantia do ato jurídico perfeito e do direito adquirido, preservadas.

8. As noções de situações concretas, subjetivadas, de direitos adquiridos, de bilateralidade eficacial, de onerosidade, de intangibilidade, de irrevogabilidade, nunca foram, portanto, estranhas aos Direitos Econômico e Tributário Nacionais.

9. No campo específico do exercício, pelo Estado, da função de incentivo, como agente regulador da atividade econômica, a natureza, por excelência, dos atos de concretização, de individualização do Direito, é a subjetivadora, a abranger, em verdade, todas as espécies de atos jurídicos de que exsurgem direitos e obrigaçōes, com o atributo da multilateralidade eficacial, da onerosidade, seja qual for a índole e designação que receberem (contratos, acordos, ajustes, compromissos, convênios, consórcios); e, mesmo que a multilateralidade e os demais aspectos decorram de um ato formalmente unilateral, mas cuja conjugação e convergência, com outros antecedentes ou ulteriores, conduzam àquele resultado.

9.1. Por isso, a participação sócio-econômico do Estado, no capítulo do Fomento Econômico, faz-se, hoje, na base da aludida consensualidade das relações entre a Administração e os particulares, de sua parceria, enfim.

9.2. É o que se chama, também, de intervençāo indireta, ou exterior, em que o Estado não se comporta como sujeito econômico e não toma parte ativa e direta no 
processo da economia nacional, manifestando-se, dentre outras formas, exatamente em estimulos à atividade das empresas, compondo o quadro dos incentivos econômicos.

Este Fomento Econômico consiste num segmento fundamental da atividade administrativa hodierna, protegendo ou promovendo atividades de sujeitos privados, situando-se privados, situando-se, portanto, no terreno das relações de parceria entre a Administração Pública e particulares.

Este apoio prestado pela AP às empresas particulares, "sujeito econômico principal de nossos dias", consiste "numa atividade de estímulo positivo e dinâmico", e não em um "mero auxílio passivo à atividade privada".

Destarte, podendo revelar-se em instrumentos formalmente contratuais, ou mesmo unilaterais, o certo é que, do ponto de vista dos efeitos, a vinculação bilateral sempre se forma, exatamente pelas prestaçöes a que o Estado se compromete, tudo a convergir sempre para a onerosidade, com a criação de direitos e obrigações.

9.3. Aliás, a troca, a simbiose entre o público e o particular são próprias da atividade incentivante.

Em verdade, se, de um lado, com a participação incentivadora, a AP compromete, pública e socialmente, a atividade privada, imputando a esta "uma dimensão de interesse público", como é próprio do Direito Econômico, que é ramo do Direito Social; de outro, o Estado, na busca, que lhe é inafastável, da realização do interesse comum, socorre-se, vale-se, neste desiderato, da atividade privada.

Esta passa a ter o selo da relevância social, a proclamação de que se trata de business affected with public interest; e por seu turno, o Estado se vincula com o particular, ainda que se utilize de instituto e instrumento de direito público.

Estamos em sede do Direito Social das Obrigaçōes.

Este dar-se recíproco, social, econômico e administrativo, traduz-se, por isso, necessariamente, na área jurídica, pela consolidação das situaçōes, pela multilateralizaçāo, pela onerosidade, mútua, pela vinculação aos compromissos assumidos e traduzidos nas prestaçôes acertadas, tudo isso a assegurar poderes garantidores do exercício dos direitos irradiados e do cumprimento das obrigaçöes avençadas.

10. Toda esta fenomenologia é geral no Direito Comparado, como mostra CABRAL DE MONCADA, em sua conhecida obra Direito Econômico (Coimbra Editora, 2s ed., 1988, p. 379 e s.).

Como é comum aos vários ordenamentos jurídicos, "o fomento econômico não se deixa encerrar numa tipologia muito definida e menos ainda dentro do espartilho de uma taxatividade legal" (op. cit., p. 350).

E, aliás, o que acontece em outros setores dos Direitos Público e Social, em que o engessamento estiolante vai dando lugar a uma fértil flexibilidade de alternativas solucionadoras. É o caso da própria estruturação administrativa, que, valendo-se dos instrumentos jurídicos mais variados, diversifica-se, caminha firme para a atipicidade, do que são exemplos a Paradministração e as diferentes espécies de entidades privadas de relevância pública e social, na linha, estes dois segmentos, da adoção de fórmulas como a dos serviços sociais autônomos, a das organizaçōes sociais, a das agências autônomas, a englobar espécies públicas e privadas de pessoas jurídicas. 
11. Identificada a relação jurídica de fomento (MONCADA, op. cit., p. 351), é claro que sua fonte pode ter natureza privatística, como no contrato de mútuo de financiamento, ou publicística, como nas variadas medidas administrativas de subvenção, de subsídio ou de incentivos fiscais, todas essas modalidades convergindo, no entanto, para a constituição da relação jurídica incentivante, com as características já tantas vezes repetida no presente estudo.

12. Os incentivos fiscais, têm, para o particular, caráter desagravatório, sob o ângulo tributário, embora pressupondo um sentido gravoso, no aspecto econômico; e, para o Estado, pelo menos de modo imediato, custoso, sob aquele ângulo; e vantajoso, sob a ótica econômico-social.

13. CABRAL DE MONCADA (op. cit., p. 351) assinala ponto de sumo relevo.

É que, se tais incentivos desonerantes têm de contar com uma base legislativa, pelo princípio da reserva legal,

"é, no entanto, prática corrente a diversificação das modalidades por via administrativa, inclusivamente por via bilateral ou 'contratual' daqueles beneficios".

Abrangendo, também, outras formas de fomento público, o Autor mencionado salienta, com propriedade (op. cit., p. 361 ):

"Simplesmente o realismo obriga-nos aqui a soluções de compromisso. Se é defensável, e desejável, o referido entendimento alargado da reserva de lei, nunca ele poderá ser tão intenso que possa eliminar por completo a presença da discricionariedade em amplas zonas da atividade prestativa, sobretudo no domínio das subvenções aos particulares. A densificação legislativa ultrapassará aqui sem dúvida a mera delimitação da competência subjetiva e objetiva (no aspecto da vinculação aos fins) da Administração. As matérias sujeitas a reserva de lei têm de ser por ela disciplinadas nos seus aspectos substanciais de maior importância.

Este nível de densificação legislativa porém não pode pretender encerrar exaustivamente o critério de decisão para o caso concreto, sobretudo em matérias onde são tão rápidas e imprevisíveis as alterações de conjuntura, a exigir do agente administrativo um esforço de permanente adaptação, que transforma a decisão administrativa num mecanismo extremamente complexo, baseado em elementos $e$ pressupostos que a lei não pode nem deve fixar integralmente. Trata-se, mais uma vez, da velha questão das relaçōes entre economia e regra jurídica. Supōe-se que aqui a compreensão do tecido estrutural do direito econômico só ganha com um assinalar de limites à previsibilidade legislativa, o que não é de modo nenhum abdicar de um entendimento reforçado do princípio da legalidade, mas tão-só relativizá-lo no confronto com certas realidades, fugindo a um excessivo dedutivismo normativo."

14. Outro tópico de expressiva significação é aquele em que o referido Autor realça (p. 352):

"Frise-se como nota final que a atribuição dos benefícios fiscais por ocasião da celebração de um contrato faz-se sempre por ato administrativo unilateral. Mesmo que as condições concretas da sua atribuição sejam objeto de estipulação contratual, não é nunca o contrato a fonte jurídica do benefício fiscal, mas apenas uma modalidade concreta da sua aplicação. Nesta perspectiva não tem o dispositivo 
convencional efeitos enquanto fonte jurídica autônoma. Trata-se simplesmente de um processo convencional de concretizaçāo do conteúdo de uma norma prevendo a outorga de um beneficio fiscal, a qual, por sua vez, se fará através de um ato administrativo."

15. Aspecto de fundamental importância é o de que o ato de concessão do incentivo econômico, com a formação da relação jurídica de fomento, é o termo final de um processo administrativo complexo, epílogo, não de meras tratativas, mas de pedidos, estudos, análises, negociaçōes.

É certo que, uma vez atribuído o incentivo, "o interesse legítimo do destinatário" - interesse que existe desde o início do processo, por evolução do simples interesse anterior - " "transforma-se num direito subjetivo do beneficiário", que, no caso do incentivo fiscal traduz-se na prestação de nāo-fazer (não lançar, na hipótese de isenção; não cobrar antes, na dilatação de prazos de pagamento) ou de fazer (conceber o abatimento no valor do tributo). Na hipótese de subsídio, a obrigação governamental é de dar, consistindo o direito subjetivo do beneficiário em "um direito de crédito a seu favor e contra a Administração", que "fica assim obrigada a proceder à entrega efetiva da importância pecuniária correspondente".

16. A existência dos consideranda no decreto concessivo do incentivo evidencia a existência desse processo, do qual aquele ato é a culminância, ato que não é regulamentar, normativo geral, in these, mas de concretização, de individualização do Direito, in casu; ato, pois, personalizado, subjetivador.

Evidencia a existência da bilateralização negocial, expressando, ademais, a motivação e a finalidade do próprio ato.

16.1. Precedente interessante, no Direito Administrativo Brasileiro e local, é o do Decreto $n^{2} 119$, de 30.12 .63 , pelo qual foram encampados serviços de bondes no Rio de Janeiro, e cujos consideranda aludiram a "entendimentos havidos", entre a antiga concessionária (Rio LIGHT S.A. - Serviços de Eletricidade e Carris e Companhia Ferro Carril do Jardim Botânico) e o Governo do então Estado da Guanabara.

Não é, pois, novidade, no Direito Brasileiro o ato decretal unilateral que corporifica o negócio jurídico, o acordo, o ajuste entre o autor do ato e seu destinatário.

$\mathrm{Na}$ referência, nos consideranda, aos "entendimentos havidos" entre o Poder Concedente e a concessionária, lê-se que esta "se obrigou", o que mostra que não se estava diante de simples tratativas, mas já do próprio negócio jurídico.

Além disso, nos arts. $5^{\circ}, 7^{\circ}$ e $9^{\circ}$ do corpo do Decreto, estão indicadas obrigações das concessionárias, inclusive quanto à desistência de açōes que haviam proposto, e ao pagamento de quantia objeto da menção nos consideranda, evidenciando que tais disposiçōes externavam o que havia sido previamente acordado entre as partes, eis que tais obrigações não poderiam, unilateralmente, derivar da vontade do autor do decreto.

A encampação é, tal como a concessão de um incentivo fiscal, produto de um ato unilateral, mas pressupostos e condições foram objeto de um negócio jurídico. Neste ponto, os artigos decretais não contêm regras, mas formalizam cláusulas negociais. 
16.2. Lembremos, outrossim, a situação das concessões de serviço público, no setor elétrico, por exemplo, antes do advento da Lei $n^{\circ}$ 8.987, de 13.02.95.

A CF de 67/69 (art. 167, II), tal como a atual (art. 175), consagrava, expressamente, o caráter contratual das mesmas.

Não obstante, já não mais se formalizavam termos de contrato, limitando-se a constituição do vínculo à expedição do decreto de delegação da prestação do serviço, eis que as regras constitucionais, legais e regulamentares passavam, ope iuris, a integrar o conteúdo natural do contrato que então se formava.

17. CABRAL DE MONCADA (op. cit., p. 379 e s.) dá realce ao fenômeno, cada vez mais intenso, da "contratualização das relações entre a Administração e os particulares", no âmbito do fomento econômico. É a consensualidade, a que dedicamos porção anterior deste trabalho.

Dentre as razões de ser dessa adjetivação contratualista, está a de "dever-se à estrutura liberal e antidirigista da ordem jurídica da economia" da maioria dos países, que é assente no reconhecimento e proteção da livre iniciativa privada, de que a liberdade contratual é expressão autorizada no domínio da disposição dos bens".

E aduz:

“ $O$ Estado dos nossos dias não pode demitir-se da prossecução do programa constitucional por um lado, mas pelo outro não pode levá-lo a cabo senão contando com a livre adesão contratual dos destinatários do programa geral de transformação estrutural de que se faz defensor. O contrato econômico é a homenagem devida pelo Estado à ordem juridica liberal da economia, pois que "a regra da liberdade contratual é o instrumento jurídico necessário à atuação do princípio econômico da livre empresa, que o Estado continua a aceitar como principio-base da atividade econômica. (MOTA PINTO, Teoria Geral do Direito Civil, 2 ed., p. 109)"

18. O contrato econômico é, portanto, uma solução de compromisso entre as exigências de regulação da atividade econômica, especialmente sob a forma de incentivo, e a estrutura liberal da ordem jurídica da economia.

Grifa MONCADA (p. 380/381):

"Representa o ponto de encontro possivel entre elas, a sua mútua adequafão, sem qualquer renúncia de parte a parte. $O$ contrato econômico é o único meio possivel através do qual o particular, livre de tomar as suas decisões econômicas, se verá conduzido a tomá-las, de acordo com a sua própria vontade, no sentido pretendido pela Administração. A intervenção unilateral do Estado substitui-se agora uma intervenção atrativa cujo sinal distintivo é o contrato."

18.1. Giza o Autor que, no domínio da colaboração da Administração com os particulares, há uma síntese da atuação administrativa unilateral com o contrato, como epílogo de um processo convencional, tendo por efeito a criação de relação jurídica obrigacional.

18.2. A convenção preliminar, mercê do consenso das partes, culmina com a prática de ato administrativo unilateral, inclusive o de concessão de incentivos fiscais, a levar a subjetivação da situação jurídica.

De um lado, a empresa ligada a um determinado comportamento econômico; em contrapartida, o Estado se obriga à concessão e manutenção de incentivos fiscais: 
"é a estrutura sinalagmática destes contratos econômicos que os torna aptos à sua função conformadora da atividade econômica".

18.3. A presença do ato unilateral no processo não desnatura a multilateralidade eficacial, nem infirma os limites à extinção da situação jurídica.

18.4. Fundamental é sublinhar que contrato é espécie do gênero ato subjetivador, e, assim, ainda que não se trate, formalmente, de contrato, mas de ato subjetivador de outra espécie, o efeito vinculativo é o mesmo.

Mesmo no Direito Privado, são fontes de obrigaçōes, atos unilaterais, como as declarações unilaterais de vontade (arts. 1.505 e s. Do Código Civil).

No Direito Público, atos-condição - que investem pessoas em situações objetivas (estututárias) criadas por lei — também revestem-se de cargas de subjetividade, inclusive por estarem em jogo direitos públicos subjetivos.

Dada a diversidade de hipóteses, e de instrumentos de fomento - como apontado por todos os estudiosos da matéria - em alguns casos o incentivo se viabilizará através da celebração de contrato. Mas, conforme também salientado, em grande parte a culminância do processo estimulativo se configurará por meio de atos unilaterais, sempre, no entanto, subjetivadores.

19. As medidas de incentivo são formas de participação imediata ou indireta dos Poderes Públicos na economia.

Outrossim, desenvolvem-se as participaçōes bilaterais ou multilaterais, segundo "tendência manifesta nos países de economia de mercado (embora a eles não se restrinja) para formas convencionais e contratuais do exercício da autoridade, procurando-se a prévia adesão dos parceiros sociais".

19.1. É o fenômeno que se chama de economia concertada, da qual uma de suas formas é a economia contratual.

A concessão de incentivos fiscais é uma das típicas modalidades de economia concertada, em que há o comprometimento recíproco da parte e da contraparte.

19.2. Como acentua CABRAL DE MONCADA, a intervenção unilateral do Estado na economia insere-se numa concepção policial, isto é, de poder de polícia, como no campo da fiscalização.

Mas, mesmo nesta área, a unilateralidade cede terreno ao ajuste, à convenção e ao contrato, "sucedendo à fase de mera polícia econômica a fase da política econômica".

19.3. O concertamento econômico, através da formação de convenções entre os parceiros, público e particular, é a institucionalização apta "a dar satisfação aos propósitos do Estado, sem violentar a situação jurídica dos indivíduos".

CABRAL DE MONCADA (op. cit., p. 45/46) disserta:

"Nesta perspectiva o Estado intervencionista não atua sempre de forma impositiva e unilateral, antes adotando uma atitude convencional para lograr os seus fins, através do recurso a técnicas consensuais. A intervenção do Estado revela assim uma certa 'privatização das suas formas (v.g. contratos-programa, contratos de desenvolvimento para a exportafão etc.) de que resulta, em boa medida, a especificidade do Direito Público da Economia. O contrato é hoje um meio normal de exercício de soberania. 
A razão de ser da opção estadual pela utilização de formas contratuais e paracontratuais (fenômeno conhecido, como já se viu, pelo nome de economia contratual), aí onde dantes os Poderes Públicos emitiam atos unilaterais regulamentares $e$ administrativos, reside no fato de por este processo se assegurar uma muito maior eficácia da decisão pública relativamente à economia. Na verdade a decisão pública passa pela mediação do seu destinatário, que passa a estar interessado na elaboração e execução dessa mesma decisão. O particular tem assim não só acesso ao processo de produção e aplicação das normas, como também se atribui à sua vontade caráter constitutivo da ação administrativa, reduzindo-se as zonas de friç̧ão entre as autoridades administrativas e os particulares, eliminando-se resistências da parte destes e acelerando a integração político-social de certas zonas muito importantes da vida econômica e social que os Parlamentos têm dificuldade em representar fielmente. Deste modo o Direito Público da Economia dá testemunho de novas exigências de participação e democracia direta e de integração política da atividade econômica, como se viu na alínéa anterior. Este fato tem provocado uma certa crise na teoria geral do direito administrativo clássico, no tocante à caracterização da atividade administrativa como atividade preferencialmente unilateral, surgindo um apreciável conjunto de Autores, quer a propor novas tipologias da atividade administrativa susceptiveis de abranger estes novos fenômenos convencionais, quer a propor novos conceitos de atos jurídicos, especificos do direito público econômico.

Sob o aspecto funcional, o interesse destes processos convencionais de fomentar a intervenção dos Poderes Públicos, na economia consiste, na linha do que já se disse, no clima de paz social e de concórdia que são susceptíveis de criar e desenvolver. A participação dos particulares na criação e execução do direito administrativo é um processo seguro de evitar friç̧ōes com as autoridades e de eliminar resistências à execução das normas de direito administrativo."

19.4. Dentro deste objetivo de busca da convergência, na atuação reguladora condensada, a subjetivação das situações é fundamental para a consecução desses fins e o afastamento de atritos e lesōes.

20. É básico considerarmos que nos encontramos no campo, não do Direito Administrativo, mas do Direito Econômico, ramo do Direito Social.

Estamos, assim, fora do campo dos contratos administrativos, da subjetividade ou objetividade regida pelo ius administrativum.

A subjetivação e a contratualização são de Direito Econômico, e, especificamente, sob a modalidade incentivante.

20.1. Não se trata, portanto, de contratação administrativa, eis que nesta o contratado - particular - passa a colaborador da $A P$, no desenvolvimento da tarefa da mesma.

No campo do fomento econômico, a posição é inversa.

Quem é colaboradora é a $A P$, que vem auxiliar o particular no desempenho de atividade do setor privado da economia.

$\mathrm{O}$ ato administrativo - seja contratual, seja unilateral - é de atribuição em favor do destinatário particular.

20.2. É certo, porém, que a noção básica de equilíbrio econômico-financeiro espraia-se, hodiernamente, por todo o Direito, muito especialmente quando presente, 
como parte, o Estado, objetivando-se a preservação do núcleo econômico que constitui o cerne de toda situação de natureza subjetiva, apresentando-se como direito adquirido básico daquele que se relaciona com o Poder Público.

21. A chamada responsabilidade civil do Estado, sua responsabilidade patrimonial, calcada no art. $37, \S 6^{2}$, da Constituição Federal, abrange, não apenas, como se costuma afirmar, a responsabilidade extracontratual, delitual, absoluta, mas abarca, igualmente, a responsabilidade civil relativa, que, ao contrário da primeira, pressupõe a existência de uma relação jurídica fechada entre o causador do dano e a vítima; responsabilidade essa última dita eficacial, eis que corresponde ao descumprimento de obrigações, à inadimplência em face de direitos subjetivos.

21.1. A propósito, escrevemos em nossos Comentários à Constituição (Rio, Freitas Bastos, 1991, p. 316/317):

"Uma questão que, desde logo, se coloca é se a disposição constitucional em comento tem por objeto, tão-somente, a responsabilidade absoluta, ou também, a responsabilidade relativa.

A responsabilidade civil do Estado, que é o rótulo que se dá à matéria em estudo (designação essa restritiva como examinamos em outro tópico destes comentários), é, na medida em que, no Direito Brasileiro, tem matriz constitucional, assunto de direito público, sendo que, na sua regulação infraconstitucional, é de direito comum, e não derrogativo desse.

Mas, enquanto com sede na $C F$, a relação jurídica que envolve dita responsabilização se coloca, no vínculo entre o responsável público, de um lado, e, de outro, o administrado, o servidor, o colaborador, o ente paradministrativo, outra entidade administrativa, como abrangente de um direito público subjetivo decorrente do próprio conteúdo da norma constitucional, em favor do lesado, e não, apenas, de uma simples expectativa de direito (e de obrigação), como se integrante do conteúdo de uma norma infraconstitucional.

Enquanto, na legislação infraconstitucional, a responsabilização é uma expectativa de direito - e de obrigação - prevista na norma legal, cuja incidência - e conseqüente subjetivação de situações jurídicas - depende da ocorrência do fato jurígeno pertinente, $o$ ato ou fato ilícito; contemplada no texto constitucional, cria-se, desde logo, para o 'terceiro' em relação à administração pública, e aos demais responsáveis, um direito subjetivo, e para aqueles um dever jurídico também de natureza pública.

Essa raiz constitucional, por outro lado, em razão da existência desse binômio direito público subjetivo $x$ dever jurídico público, faz com que se esmaeça a diferença entre responsabilidade contratual e extracontratual. Com efeito, já agora, em ambos os casos, há relação jurídica; o direito e a obrigação já existem, jả está superado o plano existencial.

Daí poder concluir-se que o responderão do dispositivo em tela abrange a responsabilidade relativa (contratual, negocial) e absoluta (delitual, extracontratual, extranegocial)."

21.2. Destarte, se o Poder Público revoga, propõe-se a extinguir ou modificar, unilateral e lesivamente, a relação jurídica de fomento, poderá o prejudicado, postular, conjuntamente, ou não, com a nulificação do ato ilícito danoso, o ressarcimento 
(termo mais apropriado do que indenizaçāo, pois que se trata de ato ilícito), pelos prejuízos causados.

21.3. Igualmente, se for tido por inválido, total ou parcialmente, o próprio ato estatal, caberá a responsabilização patrimonial do Estado.

Acerca da questão pronunciamo-nos em nossos Comentários à Constituição (p. 349):

"Assim, conforme vemos, com facilidade, no exemplo da ação popular (art. 5", LXXIII, da CF; Lei $n^{\circ}$ 4.717, de 29.06.65), a ilicitude nulificante é cumulável com $a$ ilicitude lesiva. Alguns acham que invalidade $e$ lesividade têm de ser comulativas: outros, que essa última acarreta a primeira. $O$ art. II da Lei $\left.n^{2} 4.717 / 65\right)$, estatui que 'a sentença, que, julgando procedente a ação popular, decretar a invalidade do ato impugnado, condenará ao pagamento de perdas e danos os responsáveis pela sua prática e os beneficiário dele, ressalvada a ação regressiva contra os funcionários causadores do dano, quando incorrerem em culpa'.

Esta cumulação é possível, também, em outras hipóteses. Figure-se, por exemplo, que a AP conceda uma licença para construção, que, depois, venha a anular, sem que, para a invalidade tenha concorrido o particular. Este terá direito ao ressarcimento de perdas e danos, em decorrência do erro anterior da AP."

22. No Direito Brasileiro, a defesa e efetivação dos direitos subjetivos adquiridos do incentivado poderá dar-se, em face do Estado, a par do emprego da ação de responsabilização patrimonial e das ações de invalidação, conforme antes abordado, também por meio da ação declaratória, calcada no art. $4^{2}$, I, do Código de Processo Civil, objetivando a proclamação, não só da existência, em si da relação jurídica de fomento, como o acertamento de seu próprio cónteúdo de direitos.

A ação de declaração pode ter, por si mesma, função preventiva, mas, neste campo, as açōes cautelares, o mandado de segurança também têm pertinência.

O writ repressivo, é claro, igualmente é adequado, presente o requisito de liquidez e certeza do direito. 